Research Article

\title{
Antioxidant and UV Protection Activities of Squid (Loligo sp.) Ink Powder Lotions
}

Dyah Rahmasari ${ }^{*}{ }^{*}$
Aulia Juwanti ${ }^{1}$
Ima Pratiwi ${ }^{1}$
Novia Zulfa Diana ${ }^{1}$
Raditya Weka Nugraheni ${ }^{10}$
Dita Nurlita Rakhma ${ }^{2}$
1Department of Pharmacy, Universitas
Muhammadiyah Malang, Malang, East
Java, Indonesia
2Department of Pharmacy, Universitas
Hang Tuah, Surabaya, East Java,
Indonesia
*email: dyahrahmasari@umm.ac.id
Keywords:
Antioxidant
DPPH UV Protection
Squid Ink Powder

\begin{abstract}
Melanin is a pigment contains in human skin which role as a UVabsorbing agent. One of the exogenous melanins can be obtained from squid (Loligo sp.) ink. Squid ink melanin has potent free radical protection activities. This study aimed to determine the physicochemical, stability, antioxidant, and UV protection activities of squid ink powder lotions. Squid ink powders were obtained from the drying process using $\mathrm{HCl} 0.5 \mathrm{M}$ and stored in the climatic chamber. Antioxidant activity was conducted quantitatively using the DPPH (2,2-diphenyl-1-picrylhydrazil) scavenging method. The best result of the DPPH scavenging activity was $29.12 \pm 0.023 \%$, shown from formula III. UV protection activity was conducted by observing erythema scores in animal skin, which exposure to UV. This preparation inhibits the effect of UV exposure. Squid ink powder lotions are potential as a sunscreen product.
\end{abstract}

Received: September $18^{\text {th }}, 2020$

Accepted: December 25th 2020

Published: February 28th, 2021

(C) 2021 Dyah Rahmasari, Aulia Juwanti, Ima Pratiwi, Novia Zulfa Diana, Raditya Weka Nugraheni, Dita Nurlita Rakhma. Published by Institute for Research and Community Services Universitas Muhammadiyah Palangkaraya. This is an Open Access article under the CC-BY-SA License (http://creativecommons.org/licenses/by-sa/4.0/). DOI: https://doi.org/10.33084/bjop.v4i1.1675

\section{INTRODUCTION}

Skin is the largest part of the human body located at the outermost extent, protecting the body from external environments ${ }^{1}$. One of the possible environmental factors for skin damaged is ultraviolet radiation(UVR). In continuous exposure, UVR leads to some molecular damage (DNA photodamage) and clinical damage (erythema, tanning, skin cancer, photoaging) to the skin. UVR activates matrix metalloproteinases (MMPs), which are implicated in photoaging and collagen breakdown ${ }^{23}$. The topical formulation that contains filtering or scattering UVR is called sunscreen, and the efficacy can examine by measuring the sun protection factor $(\mathrm{SPF})^{4,5}$.
One of the body's photoprotective parts, which role as a broadband UV-absorbing agent, is melanin. Melanin is a human skin pigment that acts as a protection from UVA, $\mathrm{UVB}$, and visible blue light, which has radical scavenging and antioxidant properties 6 . However, endogenous melanin does not adequately protect the skin, especially in tropical climate areas like Indonesia. Thus, it is necessary to use sunscreens containing exogenous melanin or melanin-related compounds or mimic endogenous melanin?.

One of the melanins from natural sources known to have potential as free radical scavengers are squid (Loligo sp.) ink melanin'. Squid ink plays a significant role in eliminating intracellular excessive reactive oxygen 
species (ROS) and improve its antioxidant ability ${ }^{9,10}$. It also has anti-retroviral, anti-inflammatory, antimicrobial activity, and other traditional uses ${ }^{11}$. Antioxidants can protect against photo-induced radical reactions, thereby helping sunscreens in inorganic and organic UV filters ${ }^{12}$. Also, there was a positive relation and linear correlation between sunscreen and antioxidants ${ }^{13}$.

There is currently no research on using squid ink as an active ingredient in sunscreen products because of its limitation in the low solubility of organic solvent and water ${ }^{8}$ UV-absorbing and antioxidant activity within squid ink may be used as the active compound in sunscreen lotion to increase its benefit and utilization. Lotions are emulsion dosage forms for external application to the skin, which has many characteristics like creams. Lotions consist of an oil-in-water emulsion, water washable, and widely acceptable cosmetically ${ }^{14}$. Therefore, this study investigates the physicochemical characteristics, stability, antioxidant activity, and UV protection effectivity of squid ink powder in lotion preparations.

\section{MATERIALS AND METHODS}

\section{Materials}

Squid from Sendang Biru beach was purchased from the local market in Malang city, East Java, then dried to a dry squid ink powder. The squid used was determined in the Department of Biology, Faculty of Science and Technology, Universitas Airlangga. Squid is different from cuttlefish (Sepia sp.) morphologically. The color of the ink produced by squid is blue-black, while cuttlefish produces a brownish ink color. Other materials including virgin coconut oil (VCO), cetyl alcohol, triethanolamine (TEA), stearic acid, glycerin, propylene glycol, natrium edetate, butylated hydroxytoluene (BHT), methylparaben, propylparaben, fragrance, and distilled water in technical grade for lotion preparation. The
DPPH (2,2-diphenyl-1-picrylhydrazil), ascorbic acid and methanol pro analysis for the antioxidant test, and Rattus norvegicus strain Wistar for SPF determination test's subject.

\section{Methods}

\section{Squid ink powder preparations}

Freshly obtained squids were dissected, and ink glands were manually removed from the viscera. The $50 \mathrm{~g}$ of ink squid was added with $100 \mathrm{~mL} \mathrm{HCl} 0.5 \mathrm{M}$ in a tight light condition. The solution was then stirred using a magnetic stirrer for 30 minutes then stored for 24 hours at $10^{\circ} \mathrm{C}$. After 24 hours, the solution was centrifuged for 15 minutes and dried and stored in the climatic chamber at $60^{\circ} \mathrm{C}^{15}$

\section{Squid ink powder lotion preparation}

The oil-in-water lotion was prepared with the composition as shown in Table I. The water-soluble components (part A) and the oil-soluble components (part B) were mixed at $70^{\circ} \mathrm{C}$, separately. The water phase was added to the oil phase with continuous stirring. The squid ink powder was mixed to the lotion base and added with fragrance homogeneously ${ }^{16}$.

Table I. Squid ink powder lotion formulation

\begin{tabular}{lccc}
\hline \multicolumn{1}{c}{ Ingredients } & Formula I & Formula II & Formula III \\
\hline Squid ink powder & $1 \mathrm{~g}$ & $2 \mathrm{~g}$ & $3 \mathrm{~g}$ \\
VCO & $5 \mathrm{~g}$ & $5 \mathrm{~g}$ & $5 \mathrm{~g}$ \\
Cetyl alcohol & $2 \mathrm{~g}$ & $2 \mathrm{~g}$ & $2 \mathrm{~g}$ \\
Stearic acid & $10 \mathrm{~g}$ & $10 \mathrm{~g}$ & $10 \mathrm{~g}$ \\
TEA & $2 \mathrm{~g}$ & $2 \mathrm{~g}$ & $2 \mathrm{~g}$ \\
Propylene glycol & $5 \mathrm{~g}$ & $5 \mathrm{~g}$ & $5 \mathrm{~g}$ \\
Glycerin & $8.5 \mathrm{~g}$ & $8.5 \mathrm{~g}$ & $8.5 \mathrm{~g}$ \\
Methylparaben & $0.1 \mathrm{~g}$ & $0.1 \mathrm{~g}$ & $0.1 \mathrm{~g}$ \\
Propylparaben & $0.1 \mathrm{~g}$ & $0.1 \mathrm{~g}$ & $0.1 \mathrm{~g}$ \\
BHT & $0.1 \mathrm{~g}$ & $0.1 \mathrm{~g}$ & $0.1 \mathrm{~g}$ \\
Natrium edetate & $0.1 \mathrm{~g}$ & $0.1 \mathrm{~g}$ & $0.1 \mathrm{~g}$ \\
Citrus fragrance & $\mathrm{qs}$ & $\mathrm{qs}$ & $\mathrm{qs}$ \\
Distilled water & Until $100 \%$ & Until $100 \%$ & Until $100 \%$ \\
\hline
\end{tabular}

Physicochemical evaluation of squid ink powder lotion

The physicochemical evaluation involved was organoleptic, determination of $\mathrm{pH}$ value, homogeneity, viscosity, and gel spreadability. The organoleptic test acts as a factor in the physicochemical change parameters and 
the acceptability of the preparation ${ }^{17}$. The organoleptic test was observed as its color, scent, and texture visually. $\mathrm{pH}$ value was measured using a digital $\mathrm{pH}$ meter, and homogeneity was analyzed by visual inspection for any coarse particle's existence. Viscosity was measured by Brookfield Viscometer, and gel spreadability was determined by applying gel in between two glass slides, then added with some weights ${ }^{16}$.

\section{Stability testing of squid ink powder lotion}

1. Real-time method

Real-time stability studies of the different formulations were carried out under different temperature conditions $\left(4^{\circ} \pm 2^{\circ} \mathrm{C} ; 30^{\circ} \pm 2^{\circ} \mathrm{C} ; 40^{\circ} \pm 2^{\circ} \mathrm{C}\right)$ and checked the effect on its organoleptic, homogeneity, and $\mathrm{pH}$ value. All formulations were stored in vial glass for 30 days $^{18}$.

\section{Freeze-thaw cycling method}

Freeze-thaw cycling stability studies was determined by storing the preparation in a refrigerator at $4^{\circ} \pm 2^{\circ} \mathrm{C}$ for 24 hours, then moved into a climatic chamber at $40^{\circ} \pm 2^{\circ} \mathrm{C}$ for 24 hours and counted as one cycle. This test was held in six cycles (12 days $)^{19}$.

\section{Antioxidant DPPH scavenging activity test}

This method was adapted and modified from Fatimah Zaharah and Rabeta ${ }^{20}$ as well as Saputri et al..$^{21}$. The samples with different concentrations of squid ink powder lotions and ascorbic acid as a positive control were reacted with the DPPH radical in methanol solution. About $5 \mathrm{~mL}$ of the sample (in methanol) was mixed with $1 \mathrm{~mL}$ of $0.4 \mathrm{mM}$ DPPH solution. Blank was prepared as $1 \mathrm{~mL}$ of $0.4 \mathrm{mMDPPH}$ mixed with methanol until $10 \mathrm{~mL}$. The positive control was prepared with $2 \mathrm{~mL}$ of the ascorbic acid solution and mixed with $1 \mathrm{~mL}$ of 0.4 $\mathrm{mM}$ DPPH and methanol. The mixture was mixed homogeneously using a vortex shaker and incubated for 30 minutes in dark conditions at room temperature. The absorbance was measured at $517 \mathrm{~nm}$ using a UV-Vis spectrophotometer against blank and positive control. The ability of preparations for scavenging DPPH were calculated and expressed in the term of percentage value (\%) by using the equation:

$$
\% \text { inhibitory }=\frac{A B S \text { blank }- \text { ABS sample }}{A B S \text { blank }} \times 100
$$

ABS blank : : Absorbance of blank

ABS sample : : Absorbance of sample

The half-maximal inhibitory concentration ( $\left.\mathrm{IC}_{50}\right)$ values were calculated using their calibration curve until the linear regression equation is obtained.

\section{UV protection effectivity test}

This test was determined by observing the erythema on the animal's skin test exposed to UV light. This test was using the male $R$. norvegicus strain Wistar as an experimental animal. The test was carried out by shaving the rats' back hair about $2 \mathrm{~cm} \times 2 \mathrm{~cm}$, then applying the samples and putting them on an Exo Terra lamp for six hours. Rats were divided into five groups $(n=6)$, a positive control group (using Parasol ${ }^{\mathrm{TM}}$ ), a negative control group (using lotion without active), and three sample test groups (using a lotion with $1 \%, 2 \%$, and $3 \%$ of squid ink powders) ${ }^{17}$. Parasol lotion had been clinically tested and contains active ingredients such as ethyl pmethoxycinnamate, benzophenone-3, and titanium dioxide, widely used in sunscreen preparations. This lotion had good protection against sunlight by reflecting and scattering UV radiation. The erythema score used was $0-4$ which showed no erythema $=0$; very little erythema (diameter $<25 \mathrm{~mm}$ ) = 1; erythema was clearly visible (diameter $25-30 \mathrm{~mm}$ ) =2; moderate erythema (diameter $30-35 \mathrm{~mm})=3$; and severe erythema (diameter $>35 \mathrm{~mm})=4^{22}$.

\section{Research ethics approval}

This research was approved by the Health Research Ethics Committee of Universitas Muhammadiyah 
Malang with Approval Code E.5.a/266/KEPK$\mathrm{UMM} / \mathrm{XII} / 2019$.

\section{RESULTS AND DISCUSSION}

Physicochemical evaluation of squid ink powder lotion

The squid ink powder lotions had a soft texture, black in color, and citrus scent. The black color of these lotions follows the squid ink powder's color, and formula III had sharper color than formula II and I, as shown in Figure 1. Visually, the squid ink powder lotions had no coarse particle, which indicated that the preparations were homogenous. The measurement of $\mathrm{pH}$ value, viscosity, and lotion spreadability was shown in Table II.

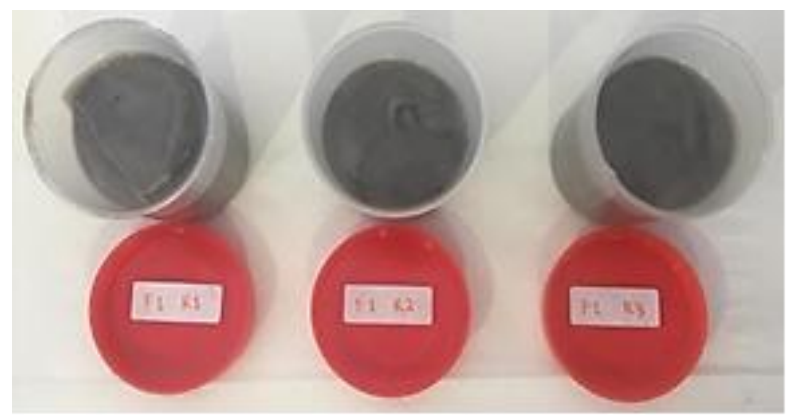

a

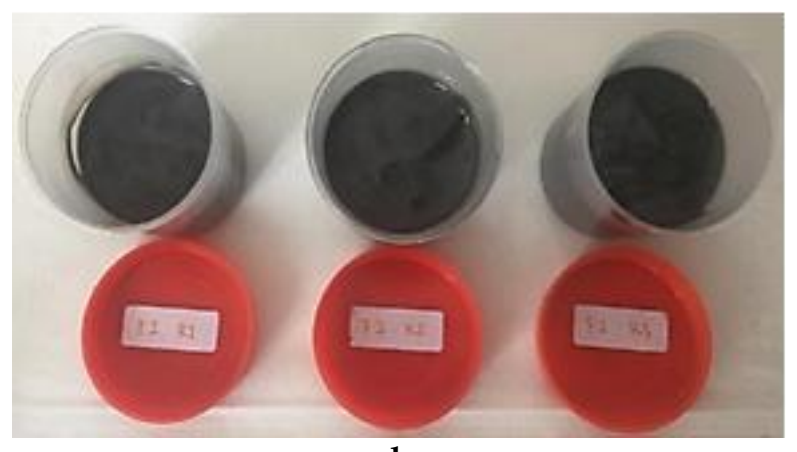

b

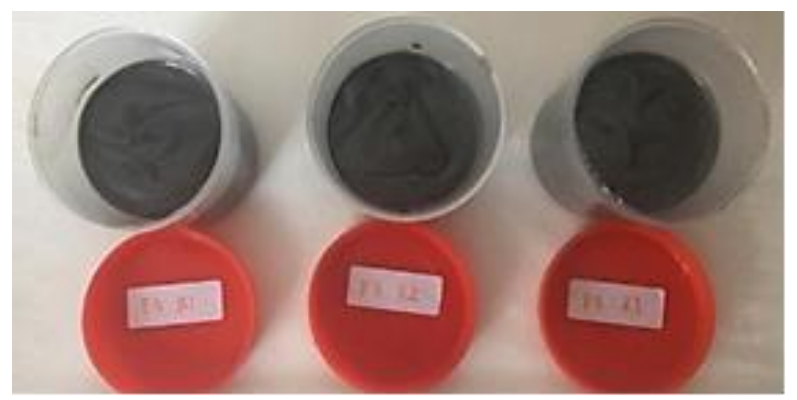

C

Figure 1. Physical appearance of squid ink powder lotions in three replications of Formula I (a); Formula II (b); and Formula III (c)
Table II. Physical and chemical characteristics of squid ink powder lotions

\begin{tabular}{cccc}
\hline Formula & pH & $\begin{array}{c}\text { Viscosity } \\
\text { (cps) }\end{array}$ & $\begin{array}{c}\text { Spreadability } \\
\text { (g/cm) }\end{array}$ \\
\hline I & $7.38 \pm 0.04$ & $3,083 \pm 629$ & $0.0037 \pm 0.0000$ \\
II & $7.30 \pm 0.02$ & $3,583 \pm 382$ & $0.0036 \pm 0.0000$ \\
III & $7.04 \pm 0.01$ & $4,667 \pm 289$ & $0.0033 \pm 0.0002$ \\
\hline
\end{tabular}

The different squid ink powder concentrations $(1 \%, 2 \%$, and $3 \%$ ) had different $\mathrm{pH}$, viscosity, and spreadability values. As shown in Table II, the higher concentration of squid ink powder resulted in lotion preparation with a lower $\mathrm{pH}$ value. This phenomenon occurred when the squid ink powder was made, the solvent $(\mathrm{HCl} \mathrm{0.5 \textrm {M } )}$ remains; hence the $\mathrm{pH}$ value was lower due to high powder content. However, the $\mathrm{pH}$ value results still qualify the $\mathrm{pH}$ range requirements of the skin tolerance $(4-7)^{23}$ and the $\mathrm{pH}$ value requirement for sunscreen preparation $(4.5-8)^{24}$. The viscosity value was significantly different and higher with the addition of squid ink powder. The spreadability value of Formula I was the highest and decreased with the addition of the active ingredient. This phenomenon proves that the higher viscosity, the lower the spreadability value ${ }^{25}$.

Stability testing of squid ink powder lotion

1. Real-time method

The results of real-time stability testing of squid ink powder lotions showed no changes in color, odor, and phase separation after storage at $4^{\circ}, 30^{\circ}$, and $40^{\circ} \mathrm{C}$. Significantly, the $\mathrm{pH}$ values were affected by the addition of squid ink powder and the storage temperature. Table III showed that the $\mathrm{pH}$ value of squid ink powder lotions was decreased over time, but the preparations were most stable at $30^{\circ} \mathrm{C}$ storage.

Table III. The $\mathrm{pH}$ value in real-time stability of squid ink powder lotion preparations

\begin{tabular}{ccccc}
\hline \multirow{2}{*}{ Formula } & \multirow{2}{*}{$\mathbf{1}^{\text {st }}$ day } & \multicolumn{3}{c}{$\mathbf{3 0}^{\text {th }}$ day } \\
\cline { 3 - 5 } & & $\mathbf{4}^{\circ} \mathbf{C}$ & $\mathbf{3 0}^{\circ} \mathbf{C}$ & $\mathbf{4 0}^{\circ} \mathbf{C}$ \\
\hline I & $7.38 \pm 0.04$ & $7.22 \pm$ & $7.20 \pm$ & $6.98 \pm$ \\
& & 0.04 & 0.07 & 0.14 \\
II & $7.30 \pm 0.02$ & $7.05 \pm$ & $7.15 \pm$ & $6.87 \pm$ \\
& & 0.01 & 0.02 & 0.03 \\
III & \multirow{2}{*}{$7.04 \pm 0.01$} & $6.85 \pm$ & $6.92 \pm$ & $6.58 \pm$ \\
& & 0.02 & 0.09 & 0.08 \\
\hline
\end{tabular}


2. Freeze-thaw cycling method

The $\mathrm{pH}$ value results of the freeze-thaw cycling test of squid ink powder lotions showed that all formulas did not change organoleptically and showed no phase separation. The $\mathrm{pH}$ value measurement results of this evaluation were shown in Table IV. The three formulas' $\mathrm{pH}$ values were different, but formula II was most stable than formula I or III.

Table IV. The $\mathrm{pH}$ value in freeze-thaw stability of squid ink powder lotion preparations

\begin{tabular}{ccc}
\hline Formula & $\mathbf{1}^{\text {st }}$ day & $\mathbf{1 2}^{\text {th }}$ day \\
\hline I & $7.38 \pm 0.04$ & $7.26 \pm 0.02$ \\
II & $7.30 \pm 0.02$ & $7.25 \pm 0,02$ \\
III & $7.04 \pm 0.01$ & $7.10 \pm 0,01$ \\
\hline
\end{tabular}

\section{Antioxidant DPPH scavenging activity test}

Antioxidant activity was examined by the DPPH scavenging method. The antioxidant will react with DPPH by electron donate mechanism, which stabilizes DPPH by decreasing the intensity of DPPH's violet color and turns into yellow ${ }^{21}$. Ascorbic acid was a positive control, which was well known as a potent antioxidant for DPPH scavenging activity. Squid ink powder showed DPPH scavenging activity, which had an $\mathrm{IC}_{50}$ value of about $46.24 \mathrm{ppm}$ (Table V). These results indicate that squid ink powder had a potent antioxidant activity, which categorized as a very powerful antioxidant $(<50 \mathrm{ppm})^{26}$.

Table V. IC $\mathrm{I}_{50}$ value of ascorbic acid and squid ink powder

\begin{tabular}{lccc}
\hline Sample & $\begin{array}{c}\text { Concentration } \\
\text { (ppm) }\end{array}$ & $\begin{array}{c}\text { DPPH scavenging } \\
\text { activity (\%) }\end{array}$ & $\begin{array}{c}\text { IC50 } \\
\text { (ppm) }\end{array}$ \\
\hline Ascorbic & 1 & $46.92 \pm 0.73$ & 1.44 \\
acid & 2 & $53.35 \pm 0.81$ & \\
& 3 & $58.94 \pm 0.80$ & \\
& 4 & $66.76 \pm 1.02$ & \\
Squid & 5 & $68.99 \pm 1.12$ & \\
ink & 5 & $17.75 \pm 0.83$ & 46.24 \\
powder & 10 & $18.28 \pm 1.25$ & \\
& 20 & $26.07 \pm 1.16$ & \\
& 50 & $26.97 \pm 1.02$ & \\
\hline
\end{tabular}

Table VI showed the scavenging activity of squid ink powder when formulated into lotion preparations. Formula III (squid ink powder 3\%) gave out the highest value in antioxidant scavenging DPPH activity compared with Formula I and II. The higher of squid ink powder concentration, the higher scavenging activity obtained. These results indicate that squid ink powder lotions were categorized as weak antioxidants (250$500 \mathrm{ppm})^{26}$. The freeze-thaw cycling test implies that the antioxidant DPPH scavenging activity of squid ink powder lotions was decreased but not significantly.

Table VI. Antioxidant DPPH scavenging activity (\%) of squid ink powder lotions

\begin{tabular}{ccc}
\hline Formula & $\begin{array}{c}\text { Before freeze-thaw } \\
(\mathbf{\%})\end{array}$ & $\begin{array}{c}\text { After freeze-thaw } \\
\mathbf{( \% )}\end{array}$ \\
\hline I & $15.83 \pm 0.013$ & $15.18 \pm 0.012$ \\
II & $20.95 \pm 0.019$ & $21.13 \pm 0.002$ \\
III & $29.12 \pm 0.023$ & $27.08 \pm 0.024$ \\
\hline
\end{tabular}

\section{UV protection effectivity test}

Erythema is induced by UV-B radiation causes cellular immunologic changes that lead to blood vessel dilation ${ }^{22}$. As shown in Table VII, this study showed that the squid ink powder lotions significantly decrease in the erythema area compared to the negative control group. These lotions were able to inhibit the effects of acute UV exposure. The presence of antioxidant activity could explain this finding. Antioxidant activity had been shown to enhance protection against $U V$-induced DNA damage by reducing oxidative stress and inhibiting NFkB. It also neutralizes the UV-induced free radicals. It made this agent could play a role as potential "nonsunscreen" agents ${ }^{27}$.

Table VII. UV protection effectivity value

\begin{tabular}{ccc}
\hline Samples & $\begin{array}{c}\text { Erythema area } \\
\left(\mathbf{m m}^{\mathbf{2}}\right)\end{array}$ & $\begin{array}{c}\text { Erythema } \\
\text { Score }\end{array}$ \\
\hline Positive control & $0 \pm 0$ & 0 \\
Negative control & $159.27 \pm 48.84$ & 4 \\
Formula I & $17.79 \pm 13.96$ & 1 \\
Formula II & $0 \pm 0$ & 0 \\
Formula III & $0 \pm 0$ & 0 \\
\hline
\end{tabular}

\section{CONCLUSION}

The 3\% squid ink powder lotion showed the best formulation of this study. It had good physicochemical characteristics and stability. It showed antioxidant 
activity with DPPH scavenging activity of $29.12 \pm 0.023 \%$ and also inhibited UV exposure. It indicates that these squid ink powder lotions had the potential as a sunscreen product.

\section{REFERENCES}

1. Boer M, Duchnik E, Maleszka R, Marchlewicz M. Structural and biophysical characteristics of human skin in maintaining proper epidermal barrier function. Postepy Dermatol Alergol. 2016;33(1):1-5. doi:10.5114/pdia.2015.48037

2. Rittié L, Fisher GJ. Natural and Sun-Induced Aging of Human Skin. Cold Spring Harb Perspect Med. 2015;5(1):a015370. doi:10.1101/cshperspect.a015370

3. Pandel R, Poljšak B, Godic A, Dahmane R. Skin Photoaging and the Role of Antioxidants in Its Prevention. Int Sch Res Notices. 2013;2013:930164. doi:10.1155/2013/930164

4. Paul SP. Ensuring the Safety of Sunscreens, and Their Efficacy in Preventing Skin Cancers: Challenges and Controversies for Clinicians, Formulators, and Regulators. Front Med. 2019;6:195. doi:10.3389/fmed.2019.00195

5. Geoffrey K, Mwangi AN, Maru SM. Sunscreen products: Rationale for use, formulation development and regulatory considerations. Saudi $\begin{array}{lll}\text { Pharm J. 2019;27(7):1009-18. } & \text { J. }\end{array}$ doi:10.1016/j.jsps.2019.08.003

6. Brenner M, Hearing VJ. The Protective Role of Melanin Against UV Damage in Human Skin. Photochem Photobiol. 2008;84(3):539-49. doi:10.1111/j.1751-1097.2007.00226.x

7. Solano F. Photoprotection and Skin Pigmentation: Melanin-Related Molecules and Some Other New Agents Obtained from Natural Sources. Molecules. 2020;25(7):1537. doi:10.3390/molecules25071537

8. Guo X, Chen S, Hu Y, Li G, Liao N, Ye X, et al. Preparation of water-soluble melanin from squid ink using ultrasound-assisted degradation and its antioxidant activity. J Food Sci Technol. 2014;51(12):368090. doi:10.1007/s13197-013-0937-7

9. Fitrial Y, Khotimah IK. Antibacterial Activity of Melanin from Cuttlefish and Squid Ink. Jurnal
Pengolahan Hasil Perikanan Indonesia. 2017;20(2):266-74. doi:10.17844/jphpi.v20i2.17907

10. Chen Y, Liu H, Huang H, Ma Y, Wan R, Hu Y, et al. Squid Ink Polysaccharides Protect Human Fibroblast Against Oxidative Stress by Regulating NADPH Oxidase and Connexin43. Front Pharmacol. 2019;10:1574. doi:10.3389/fphar.2019.01574

11. Nadarajah SK, Vijayaraj R, Mani J. Therapeutic Significance of Loligo vulgaris (Lamarck, 1798) ink Extract: A Biomedical Approach. Pharmacognosy Res. 2017;9(Suppl1):S105-9. doi:10.4103/pr.pr_81_17

12. Latha MS, Martis J, Shobha V, Shinde RS, Bangera S, Krishnankutty B, et al. Sunscreening Agents: A Review. J Clin Aesthet Dermatol. 2013;6(1):16-26.

13. Ebrahimzadeh MA, Enayatifard R, Khalili M, Ghaffarloo M, Saeedi M, Charati JY. Correlation between Sun Protection Factor and Antioxidant Activity, Phenol and Flavonoid Contents of some Medicinal Plants. Iran J Pharm Res. 2014;13(3):1041-7.

14. Purnamawati S, Indrastuti N, Danarti R, Saefudin T. The Role of Moisturizers in Addressing Various Kinds of Dermatitis: A Review. Clin Med Res. 2017;15(3-4):75-87. doi:10.3121/cmr.2017.1363

15. Nitsae M, Karpada E, Banamtuan A, Ledo MES, Mauboy RS, Sabuna AC. Uji Ketahanan Luntur dan Karakterisasi Serbuk Tinta Cumi-Cumi (Loligo sp.) sebagai Dasar Pewarna Hitam untuk Kain Tenun Ikat Asal Nusa Tenggara Timur. Biota Jurnal Ilmiah Ilmu-Ilmu Hayati. 2017;2(3):89-96. doi:10.24002/biota.v3i2.1884

16. Saptarini NM, Hadisoebroto G. Formulation and evaluation of lotion and cream of nanosized chitosanmangosteen (Garcinia mangostana L.) pericarp extract. Rasayan J Chem. 2020;13(2):789-95. doi:10.31788/RJC.2020.1325533

17. Amatullah L, Cahyaningrum TN, Fidyaningsih AN. Antioxidants Effectivity In Skin Lotion Formulation Of Mesocarp Fruit Extract Lontar (Borassus Flabellifer) Against White Rats Wistar Male In-Situ. JPSCR J Pharm Sci Clin Res. 2017;2(1):25-34. doi:10.20961/jpscr.v2i1.5236

18. Kumar A, Dua JS. Formulation and Evaluation of Itraconazole Niosomal Gel. Asian J Pharm Res Dev. 2018;6(5):76-80. doi:10.22270/ajprd.v6i5.425

19. Fitriani EW, Imelda E, Kornelis C, Avanti C. Karakterisasi dan Stabilitas Fisik Mikroemulsi Tipe 
A/M Dengan Berbagai Fase Minyak. Pharm Sci Res. 2016;3(1):31-44. doi:10.7454/psr.v3i1.3221

20. Fatimah Zaharah MY, Rabeta MS. Antioxidant and antimicrobial activities of squid ink powder. Food Res. 2018;2(1):82-8. doi:10.26656/fr.2017.2(1).225

21. Saputri R, Melati TMR, Fitriyanti F. Antioxidant Activity of Ethanolic Extract from Tandui Leaves (Mangifera rufocostata Kosterm.) by DPPH Radical Scavenging Method. Borneo J Pharm. 2019;2(2):114-8. doi:10.33084/bjop.v2i2.1070

22. Krismayogi GA, Ratnayanti IGAD, Linawati NM, Wiryawan IGNS, Sugiritama IW, Wahyuniari IAI, et al. Purple Cabbage Extract Cream Effect on Erythema Score of Male Wistar Rats Back Skin Exposed to UVB Radiation. Biomed Pharmacol J. 2018;11(1):343-51. doi:10.13005/bpj/1378

23. Lambers H, Piessens S, Bloem A, Pronk H, Finkel P. Natural skin surface $p H$ is on average below 5 , which is beneficial for its resident flora. Int J Cosmet Sci. 2006;28(5):359-70. doi:10.1111/j.14672494.2006.00344.x

24. Badan Standarisasi Nasional. Sediaan Tabir Surya. SNI 16-4399-1996. Jakarta, Indonesia: Badan Standarisasi Nasional; 1996.

25. Deuschle VCKN, Deuschle RAN, Bortoluzzi MR, Athayde ML. Physical chemistry evaluation of stability, spreadability, in vitro antioxidant, and photo-protective capacities of topical formulations containing Calendula officinalis L. leaf extract. Braz J Pharm Sci. 2015;51(1):63-75. doi:10.1590/S198482502015000100007

26. Molyneux P. The use of the stable free radical diphenylpicrylhydrazyl (DPPH) for estimating antioxidant activity. Songklanarin J Sci Technol. 2004;26(2):211-9

27. Tan BL, Norhaizan ME, Liew WPP, Rahman HS. Antioxidant and Oxidative Stress: A Mutual Interplay in Age-Related Diseases. Front Pharmacol. 2018;9:1162. doi:10.3389/fphar.2018.01162 